\title{
Prevalence of canid herpesvirus-1 infection in stillborn and dead neonatal puppies in Denmark
}

\author{
Rikke W Larsen ${ }^{1 *}$, Matti Kiupel ${ }^{2}$, Hans-Jörg Balzer ${ }^{3}$ and Jørgen S Agerholm
}

\begin{abstract}
Background: Canid herpesvirus-1 (CaHV-1) infection in puppies less than three weeks of age is often reported to be associated with a lethal generalized necrotizing inflammation and since the discovery of the virus in 1965 several reports of neonatal infections have been published. However, the significance of CaHV-1 for peri- and neonatal mortality in puppies remains unclear. Therefore, we examined stillborn and dead neonatal puppies in Denmark to determine the prevalence of infection and further to correlate infection levels with necropsy findings to assess the possible significance of the infection.

Results: From a cross-sectional study of 57 dead puppies, 22.8\% $(n=13)$ were confirmed positive for CaHV-1 by real-time polymerase chain reaction (PCR) of tissue pools of lung/liver and/or spleen/kidney. Specimens from PCR positive cases were further investigated by histology and in situ hybridization (ISH). High levels of CaHV-1 DNA were present in only one case in which lesions and ISH staining consistent with CaHV-1 infection were found as well. CaHV-1 concentrations in the other cases were low and a range of lesions not consistent with CaHV-1 were found. Similar, ISH staining was mostly negative in these except for one case with a few positive cells.

Conclusion: CaHV-1 infection in stillborn and dead neonatal puppies in Denmark seems to be common, but the direct significance for puppy mortality remains unclear as only one of 13 PCR positive puppies (7.7\%) had pathognomonic lesions.
\end{abstract}

Keywords: Canid herpesvirus-1, CaHV-1, Viral infection, Neonatal, Puppies, PCR, In situ hybridization

\section{Background}

Canid herpesvirus-1 (CaHV-1) is an enveloped double stranded DNA virus belonging to the family Herpesviridae, subfamily Alphaherpesviridae, genus Varicellovirus [1]. CaHV-1 is phylogenetically related to $\alpha$-herpesviruses affecting other animal species but surface receptors limit the host range of CaHV-1 to domestic dogs and other Canidae [2]. CaHV-1 was first reported by Carmichael et al. [3] as a cytopathic agent associated with a systemic fatal hemorrhagic infection in neonatal puppies by causing focal necrosis of parenchymal organs. The infection is usually asymptomatic or restricted to the upper airways or the genital tract in adult dogs, although infection of pregnant bitches may cause embryonic loss, abortion and stillbirth [3-6]. The immature status of newborn puppies makes them

\footnotetext{
* Correspondence: rikkewendtlarsen@gmail.com

'Section for Veterinary Reproduction and Obstetrics, Department of Large Animal Sciences, Faculty of Health and Medical Sciences, University of Copenhagen, Dyrlægevej 68, Frederiksberg DK-1870, Denmark

Full list of author information is available at the end of the article
}

vulnerable to a systemic CaHV-1 infection as resistance seems to be correlated to the maturity of the immune system and thermoregulation $[7,8]$.

Newborn puppies are usually suspected to have acquired the infection from oronasal secretions of the bitch, infected littermates or from other dogs in the household $[9,2]$ though neonatal disease may also occur following intrauterine infection or from viral infection during passage through the birth canal [4-6].

The neonatal mortality rate in dogs is generally considered high although only a few studies have been published. Indrebø et al. [10] emphasized that the canine mortality within the first eight weeks of life may reach $17-30 \%$. Other studies have identified bacterial infections and fetal asphyxia as the main causes of puppy mortality $[11,12]$. Reports of fatal neonatal CaHV-1 infections have been published $[13,14]$ and even though serological studies from many European countries indicate that CaHV-1 infection is widespread in adult dogs, with antibody prevalence ranging from 40-88\% [14-18] CaHV-1 is not considered to be a major cause of mortality in puppies [10-12]. 
However, information on the prevalence of CaHV-1 infection in neonatal dogs is sparse.

The aim of this study was to determine the prevalence of CaHV-1 infection in stillborn puppies and puppies dying within the first three weeks of life in Denmark and further to access the significance of the infection based on post mortem findings.

\section{Material and methods}

\section{Study design, sampling and necropsy}

The study was performed as a cross-sectional necropsy study from September 2012 to April 2013 based on stillborn puppies and puppies that died or were euthanized during their first three weeks of life. Information about the project was sent to 300 companion animal clinics throughout Denmark and also advertised on the internet. Breeders and veterinarians were asked to keep the dead puppies at $5^{\circ} \mathrm{C}$ until shipment, which should be done cooled. The submission was accompanied with a form including historical data such as breed, litter size, litter mortality, clinical signs and vaccination status for CaHV-1. Fifty-seven puppies originating from 37 litters and being of 26 different breeds formed the overall study population (see Additional file 1). Twenty-one cases were stillborn, 25 cases were aged from 1 to 7 days and 11 cases were older than 7 days. The age of puppy no. 33 was unknown as the submission was not accompanied by a form but it was estimated to a few days old based on the developmental stage. The submitted puppies originated from most parts of Denmark (see Additional file 2).

The puppies were necropsied upon arrival at the University and specimens were taken for histology and real-time polymerase chain reaction (PCR). Two tissue pools were sampled for PCR, i.e. liver/lung and spleen/ kidney pools, when available and stored at $-70^{\circ} \mathrm{C}$. The time between death and necropsy varied from hours to days.

Specimens for histology and in situ hybridization (ISH) were taken from brain, heart, lung, liver, spleen, kidney and adrenal gland if tissues were available/suitable and fixed in $10 \%$ neutral buffered formalin, processed by routine methods, sectioned at $3 \mu \mathrm{m}$ and stained with hematoxylin and eosin.

\section{Real-time PCR}

Quantification of CaHV-1 DNA was done by a semi quantitative approach applying a real-time PCR assay at IDEXX Vet Med Laboratories, Ludwigsburg, Germany targeting a $116 \mathrm{bp}$ fragment of the CaHV-1 DNA polymerase gene.

Samples were shipped overnight on dry ice to the laboratory where about $10 \mathrm{mg}$ of each organ in a pool was comminuted and mixed with $180 \mu \mathrm{l}$ ATL (QIAGEN, Hilden, Germany) and $20 \mu \mathrm{l}$ Proteinase $\mathrm{K}$ solution (QIAGEN). Total nucleic acid was extracted from the tissues by using the QIAamp DNA Mini Kit (QIAGEN) according to the manufacturer's instructions. PCR was performed using the LightCycler 480 system (Roche Diagnostics, Mannheim, Germany) with proprietary forward and reverse primers and a hydrolysis probe. The PCR was run with five quality controls, including a 1) PCR positive control, 2) PCR negative control, 3) negative extraction controls, 4) internal positive control (IPC) spiked into the lysis solution to monitor the nucleic acid extraction efficiency and presence or absence of inhibitory substance and 5) an environmental contamination monitoring control.

Samples were considered positive if the amplification exceeded the threshold within 45 repeated cycles. Results were given as crossing point values $(\mathrm{Cp}$, the point at which the fluorescence of a sample rises above the background fluorescence) of undiluted, 1:10 and 1:100 dilutions (See Additional file 3). Samples with $\mathrm{Cp}>40$ (flagged as "Late Cp call" (last five cycles) with a higher uncertainty by the LightCycler 480 software) were repeated in duplicate. If the $C p$ value could be reproduced in repeated analysis, the sample was considered positive, though indicative of a minimal amount of total viral DNA. The crossing points were calculated applying the Second Derivative Maximum method to standardize Cp calling.

As a sample's $\mathrm{Cp}$ depends on the initial concentration of DNA in the sample the correlation between DNA concentration and $\mathrm{Cp}$ is inversed: A sample with a lower initial concentration of target DNA requires more amplification cycles to reach the $\mathrm{Cp}$ and a sample with higher concentration requires fewer cycles.

\section{In situ hydridization}

In situ hybridization for CaHV-1 was performed on serial sections of formalin-fixed, paraffin-embedded tissues using an automated slide-processing system as previously described [19]. Briefly, sections of the selected tissue samples were prepared at $5 \mu \mathrm{m}$ thickness and placed on positively charged slides. These slides were then submitted to deparaffinization and fixation using the Discovery XT automated slide processing system (Ventana Medical Systems, Inc., Tucson, AZ), as programed in the protocol for RiboMap ISH reagent system (Ventana Medical Systems). Proteolytic treatment was performed using Protease 3 (0.02 units $/ \mathrm{ml}$ alkaline protease, Ventana Medical Systems) for $12 \mathrm{~min}$ at $37^{\circ} \mathrm{C}$. Thereafter, the slides received pre-treatment through standard cell conditioning using the citrate buffer-based RiboCC reagent (Ventana Medical Systems) for $4 \mathrm{~min}$ at $95^{\circ} \mathrm{C}$. The slides were then submitted to denaturation for $4 \mathrm{~min}$ at $95^{\circ} \mathrm{C}$, followed by hybridization with a digoxigenin-labeled oligonucleotide probe (DIG-5'-GATATTGTGCAAGGTATATACTCAG TACAAGACCGGAAGCTGC-3') that targets a highly conserved region of the TK gene sequence of $\mathrm{CaHV}-1$ 
(nucleotide positions 330-372, GenBank Acc. No. D83054) suspended in hybridization buffer (RiboHybe, Ventana Medical Systems). The time of hybridization was $2 \mathrm{~h}$ at $42^{\circ} \mathrm{C}$. The concentration used for the generic probe was $682 \mathrm{ng} / \mathrm{ml}$ (dilution 1:1,000). For the generic probe, three stringency washing steps were performed using $2.0 \times$ RiboWash (Ventana Medical Systems; equivalent to $2.0 \times$ saline sodium citrate) each for $4 \mathrm{~min}$ at $52^{\circ} \mathrm{C}$. After the stringency washes, the slides were incubated with anti-digoxigenin antibody for $32 \mathrm{~min}$ at $37^{\circ} \mathrm{C}$. The anti-digoxigenin antibody was a rabbit monoclonal antidigoxigenin antibody (Invitrogen Corporation, Frederick, MD) used at the dilution of 1:10,000. After streptavidinalkaline phosphatase conjugate (UMap anti-Rb AP, Ventana
Medical Systems) incubation for $24 \mathrm{~min}$ at $37^{\circ} \mathrm{C}$, the signal was detected automatically using the BlueMap NBT/BCIP substrate kit (Ventana Medical Systems) for $44 \mathrm{~min}$ at $37^{\circ} \mathrm{C}$. Finally, the sections were counterstained with the nuclear fast red equivalent reagent Red Counterstain II (Ventana Medical Systems) for 4 min before coverslipping. Tissue sections of a young puppy naturally infected with CaHV-1 were used as a positive control. For the negative reagent controls, sections were treated only with RiboHybe hybridization buffer.

\section{Histopathology}

Tissue sections from PCR positive cases were examined and the most significant lesions recorded (Table 1). CaHV-1 was

Table 1 Findings in 13 puppies from 11 litters found positive for canid herpesvirus-1 by real-time polymerase chain reaction (PCR)

\begin{tabular}{|c|c|c|c|c|c|c|}
\hline \multirow[t]{2}{*}{ Litter no. } & \multirow[t]{2}{*}{ Puppy no. } & \multirow{2}{*}{$\begin{array}{l}\text { Time of death } \\
\text { (Days post } \\
\text { partum) }\end{array}$} & \multicolumn{2}{|c|}{ PCR (Cp value) } & \multirow[t]{2}{*}{ Most significant lesions } & \multirow[t]{2}{*}{ In situ hybridization } \\
\hline & & & Liver/lung & Spleen/kidney & & \\
\hline 1 & 1 & 13 & 13.3 & 13.9 & $\begin{array}{l}\text { Acute disseminated necrosis in } \\
\text { multiple tissues with intranuclear } \\
\text { inclusion bodies }\end{array}$ & $\begin{array}{l}\text { Strong labeling was detected } \\
\text { in nuclei of cells in close proximity } \\
\text { to focal areas of necrosis including } \\
\text { hepatocytes, adrenal cortical cells, } \\
\text { renal tubular epithelial cells, } \\
\text { bronchial epithelial cells and } \\
\text { pneumocytes. }\end{array}$ \\
\hline 2 & 2 & 12 & 29.5 & 31.4 & $\begin{array}{l}\text { Focal liver abscess. Mild macrocytic } \\
\text { aspiration bronchopneumonia }\end{array}$ & $\begin{array}{l}\text { A few ISH positive cells, most } \\
\text { suggestive of macrophages based } \\
\text { on morphology, were found in } \\
\text { the liver, spleen and kidney }\end{array}$ \\
\hline \multirow[t]{2}{*}{3} & 3 & 2 & 32.8 & 32.6 & $\begin{array}{l}\text { Mild macrocytic aspiration } \\
\text { bronchopneumonia. Severe } \\
\text { hepatic congestion. }\end{array}$ & Negative \\
\hline & 4 & 3 & 32.9 & 32.5 & Mild interstitial suppurative hepatitis & Negative \\
\hline 4 & 7 & 12 & 37.8 & 36.7 & $\begin{array}{l}\text { Hepatomegaly. Widespread splenic } \\
\text { single cell necrosis }\end{array}$ & Negative \\
\hline 5 & 8 & 0 & 34.0 & NA & Severe autolysis. Inconclusive & ND \\
\hline 6 & 11 & 17 & Negative & $>40^{*}$ & $\begin{array}{l}\text { Hepatomegaly, splenomegaly and } \\
\text { renomegaly. Alveolar hemorrhage } \\
\text { and erythrophagocytosis }\end{array}$ & Negative \\
\hline \multirow[t]{2}{*}{7} & 12 & 0 & $>40$ & 39.4 & Severe autolysis. Inconclusive & ND \\
\hline & 13 & 0 & 34.8 & 36.9 & Severe autolysis. Inconclusive & Negative \\
\hline 8 & 15 & 0 & 35.7 & $>40$ & $\begin{array}{l}\text { Polydactyli. Congenital atelectasis. } \\
\text { Mild aspiration bronchopneumonia }\end{array}$ & Negative \\
\hline 9 & 16 & 14 & 38.9 & Negative & $\begin{array}{l}\text { Acute severe necrotizing and } \\
\text { suppurative bronchopneumonia. } \\
\text { Hepatomegaly and splenomegaly. }\end{array}$ & Negative \\
\hline 10 & 17 & 1 & 33.6 & $>40$ & Mild macrocytic bronchopneumonia & Negative \\
\hline 11 & 18 & 14 & 31.3 & Negative & $\begin{array}{l}\text { Acute severe suppurative } \\
\text { bronchopneumonia. Widespread } \\
\text { acute suppurative interstitial hepatitis. } \\
\text { Hepatomegaly, splenomegaly and } \\
\text { renomegaly. Follicular purulent } \\
\text { dermatitis. }\end{array}$ & Negative \\
\hline
\end{tabular}


considered as the cause of death if pathognomonic multifocal coagulation necrosis were observed.

\section{Results}

Fifty-seven puppies from 37 different litters formed the overall study population. The number of dead puppies per litter varied from one to eight, but submission of all dead puppies was not achieved in all cases (see Additional file 1). Analysis and statistical comparisons of historical data and potential risk factors e.g. litter size, clinical signs and litter mortality was inconclusive due to the low number of puppies (data not shown).

PCR analysis identified 13 puppies as being infected by CaHV-1 (22.8\%). In the group of puppies older than 7 days, six puppies (54.5\%) were positive for CaHV-1 DNA. Furthermore, three of 25 cases (12.0\%) aged from 1 to 7-days-old and four of 21 stillborn puppies (19.0\%) had detectable levels of CaHV-1 DNA in the organs.

One case (Puppy 1) had high levels of CaHV-1 DNA in both tissue pools, while the other puppies had low levels with $\mathrm{Cp}$ values mostly above 30 . CaHV-1 DNA amounts in the two tissue pools (lung/liver and spleen/ kidney) were usually at the same level although some cases were negative in one pool and positive in the other (Table 1).

Puppy no. 19 tested negative for CaHV-1 in the tissue pools but the heart that was tested by a mistake was found positive in two independent DNA isolations $\left(1^{\text {st }}\right.$ preparation $\mathrm{Cp}(1: 10)=38.2$ and $2^{\text {nd }}$ preparation $\mathrm{Cp}$ (undiluted) $\left.>40\right)$. see Additional file 3 for details. The puppy was not included in the test positive group as this group was defined as puppies being positive in lung/liver and/or spleen/kidney.

Necropsy and subsequent histological examination of tissues from PCR positive puppies revealed a wide range of lesions of which the most significant are reported in Table 1 . Three stillborn puppies $(8,12$ and 13$)$ had severe autolysis due to intrauterine death and retention. This compromised gross examination and hindered histology. Almost complete sets of tissues were available in the other cases although they displayed a certain degree of autolysis. Parts of the cranial mesenterial ganglion were included in the sections of the adrenal gland in seven cases.

Only puppy no. 1 had lesions consistent with a fulminant CaHV-1 infection, i.e. hepatomegaly, splenomegaly and bilateral renomegaly associated with widespread hemorrhages (Figure 1) that was histologically confirmed as being associated with acute disseminated necrosis in the lung, myocardium, liver, kidney and adrenal gland (Figure 2A,B) with presence of intranuclear eosinophilic inclusions bodies (Figure 3).

Significant ISH staining was only found in puppy no. 1 (Figure 4). Strong labeling was detected in nuclei of cells in close proximity to focal areas of necrosis including

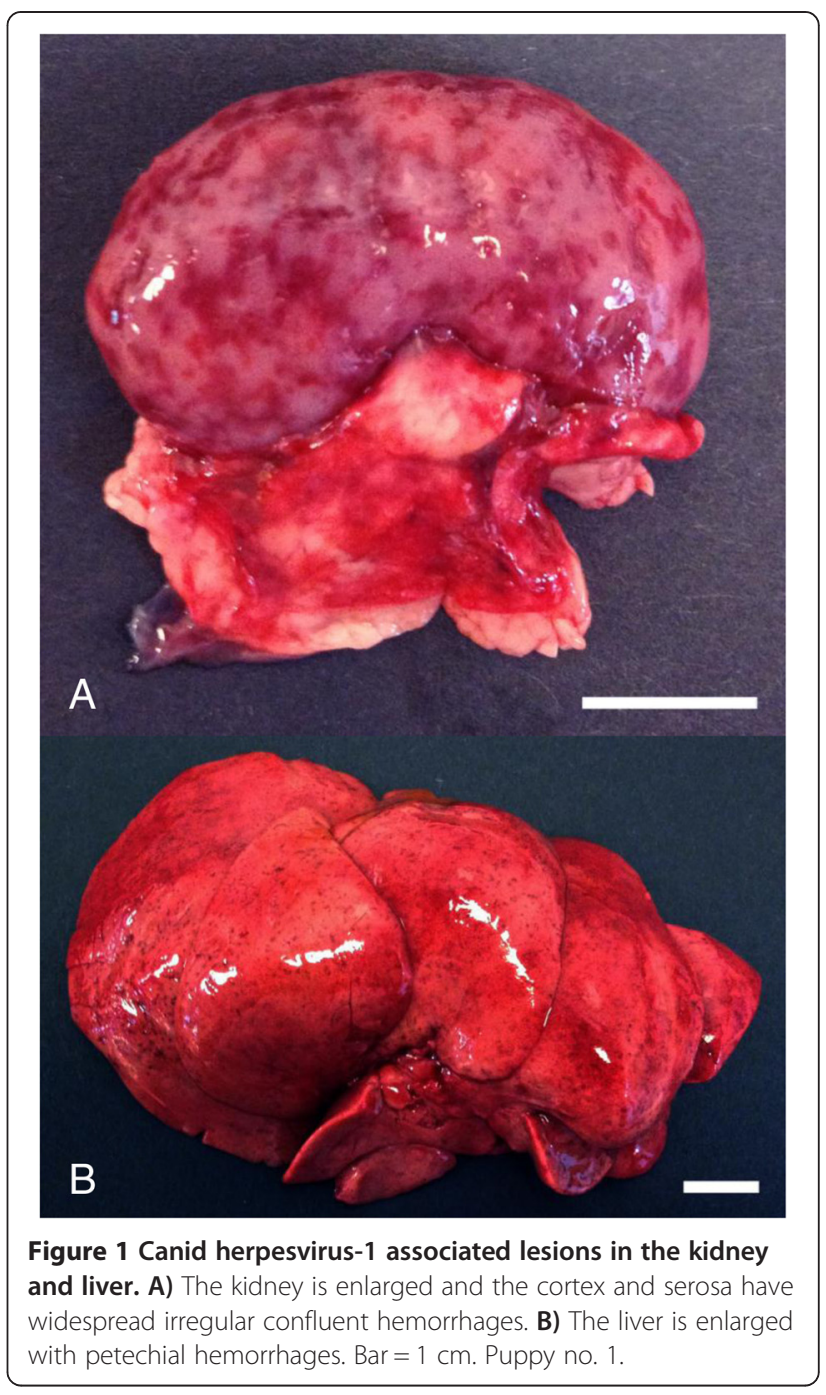

hepatocytes, adrenal cortical cells, renal tubular epithelial cells, bronchial epithelial cells and pneumocytes. In areas of necrosis and inflammation, positive signal was also detected in nuclei of endothelial cells and macrophages. A few ISH positive cells, most suggestive of being macrophages based on morphology, were found in the liver, spleen and kidney of puppy 2 . The remaining puppies were negative (Table 1).

Based on the historical information obtained from the breeders, only one bitch (litter 3) had been vaccinated against CaHV-1. This was done as a two dose regime during pregnancy according to the manufacture's protocol. Three of 10 puppies from her litter died during the neonatal period and were submitted. Two of the puppies were positive by PCR (puppy nos. 3 and 4) (Table 1). No interference of bitch vaccination and detection of CaHV-1 DNA in puppies are to be expected as the vaccine contains glycoproteins of the virus that is not transmitted in utero/transplacental. These three puppies had nursing problems during their first $24 \mathrm{~h}$ of life and probably received sparse amounts of colostrum. 


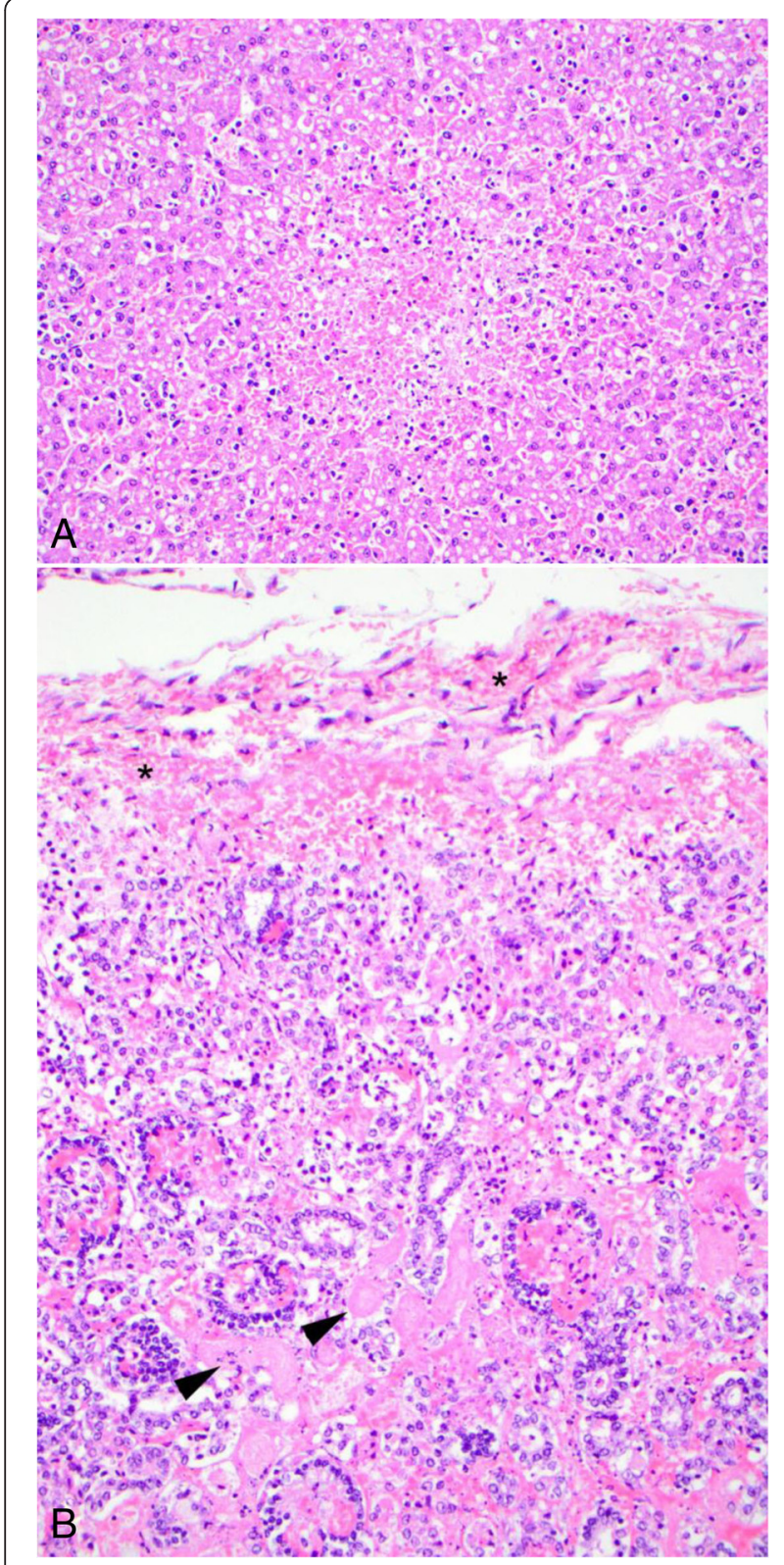

Figure 2 Microphotographs of canid herpesvirus-1 associated lesions in the liver and kidney. A) Acute focal necrosis of the liver parenchyma with central hemorrhage. B) Acute tubular necrosis (arrowheads) in the renal cortex. Grossly visible hemorrhages are present in the superficial cortex and serosa (asterisk). Hematoxylin and eosin. Puppy no. 1

\section{Discussion}

CaHV-1 infection was found in puppies originating from most areas of Denmark and puppies of different breeds were affected. Although it is difficult to extrapolate from a study based on examination of 57 dead puppies from 37 litters to the Danish dog population in general, these findings still indicate that CaHV-1 occurs widely in the Danish dog population similarly as previously reported from other North European dog populations [14-18].

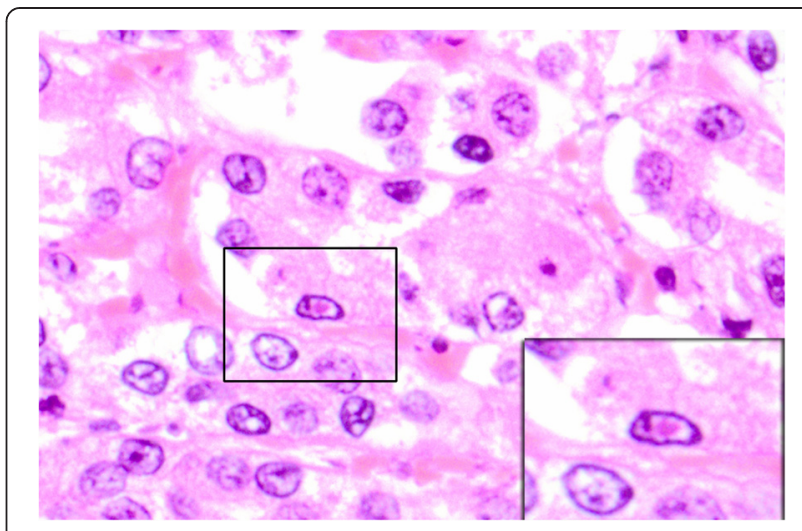

Figure 3 Eosinophilic intranuclear inclusion body. Acute tubular necrosis in the renal cortex with a canid herpesvirus-1 intranuclear inclusion body (insert). Hematoxylin and eosin. Kidney. Puppy no. 1.

The overall prevalence of CaHV-1 infection in this study was $22.8 \%$, but it varied between age groups. Although not statistically significant, the infection was most prevalent in puppies older than seven days (54.5\%) while $19.0 \%$ and $12.0 \%$ of stillborn and puppies aged 1 to 7 days were PCR positive, respectively (see Additional file 1). This probably reflects factors such as an age dependent exposure risk and viral incubation period. Congenital infections seem to be rather common as $19.0 \%$ of the stillborn puppies were PCR positive and might reflect the possibility for the virus to be transmitted to the fetus in utero. Transplacental transmission of CaHV-1 has previously been shown to cause stillbirth in experimentally inoculated pregnant bitches $[4,5]$. Our study, however, could not directly correlate the cause of death in the stillborn puppies with CaHV-1 infection.

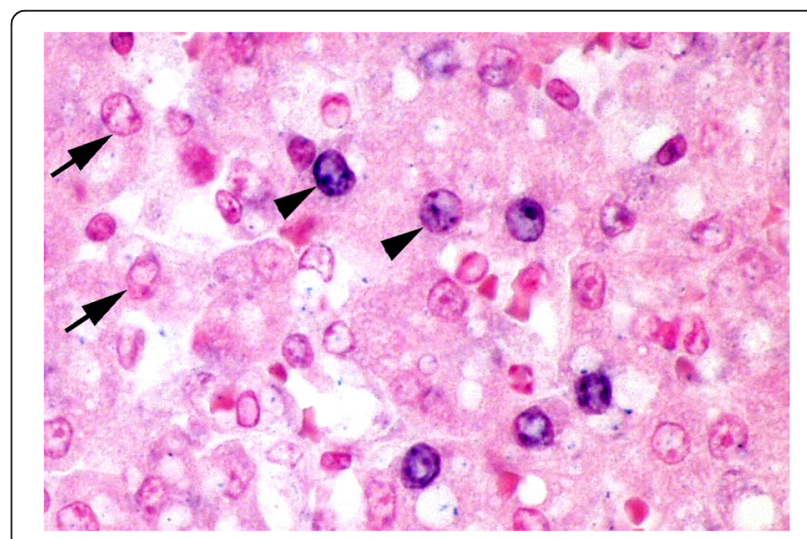

Figure 4 Intranuclear canid herpesvirus-1 (CaHV-1) DNA labeled with in situ hybridization. Multiple hepatocytes have CaHV-1 positive nuclei (arrowheads) seen as blue labeling. Examples of negative nuclei just counter stained by nuclear fast red are indicated by arrows. Liver. Puppy no. 1 . 
Only one puppy (no. 1) had lesions consistent with a fulminant CaHV-1 infection. These lesions correlated well with a high infection level and positive ISH labeling (Table 1). The significance of the infection for the other 12 puppies remains speculative due to the absence of pathognomic lesions and low infection levels. As the study was performed as a cross sectional necropsy study of spontaneously diseased puppies, a wide range of conditions have probably influenced the results, which is a limitation of such a study type. Exposure dose and time, stage of infection, colostrum intake, colostrum antibody levels, concomitant diseases and environmental influences are just some factors that may affect the course of infection and these factors were unknown in the present study.

Some of the puppies had lesions consistent with a bacterial disease, i.e. suppurative inflammation, while others had lesions indicative of intrauterine stress, such as congenital pneumonia associated with aspiration of amniotic epithelial cells. Infection with CaHV-1 may have predisposed puppies to other infectious causes or aggravated their course. Some puppies surviving an expected lethal oronasal challenge with a virulent CaHV-1 strain at three days of age had PCR positive lung and kidney samples 24 days post inoculation [20]. Inoculated puppies were small and underweight, with lesions of subacute interstitial pneumonia and subacute interstitial nephritis. Similar to the results presented here, characteristic CaHV1 lesions were absent in the organs examined microscopically [20]. These data further support the hypothesis that a sublethal infection with CaHV-1 may predispose affected puppies to secondary bacterial infections. Widespread herpesviral infection has also been detected by PCR in non-canine species without associated characteristic lesions [21]. In one study, 6 of 10 seal pups were positive for phocine herpesvirus-1 (PhHV-1) but did not have histopathological evidence of characteristic viral lesions [21]. One premature animal died of a systemic PhHV-1 infection and three others had varying degrees of necrosis in the adrenal glands and liver, though died of other courses. Other positive cases without characteristic lesions were considered to have recovered from a clinical infection with detectable antibodies against the virus [21]. This phenomenon may explain at least some of the PCR findings in the present study, particularly in the older puppies which may have experienced a sublethal infection or may have recovered from a clinical infection but died of other courses or were euthanized due to weakness.

\section{Conclusion}

CaHV-1 infection was diagnosed in $22.8 \%$ of 57 puppies that died or were euthanized during the first three weeks of life thus indicating that CaHV-1 infection is common in Danish puppies. Presence of viral DNA was more prevalent than characteristic CaHV-1 lesions and only one puppy was diagnosed with a systemic CaHV-1 infection.

\section{Additional files}

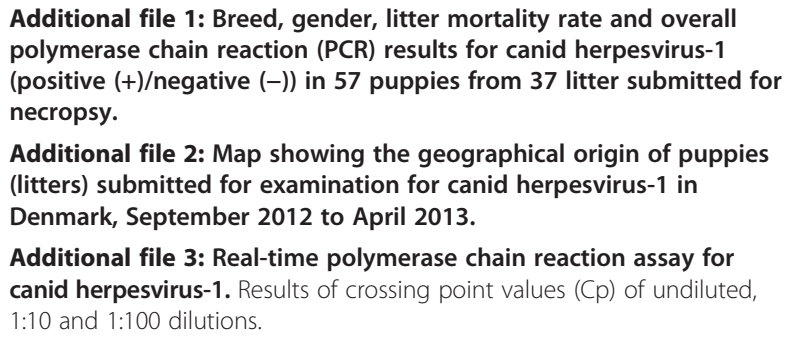
polymerase chain reaction (PCR) results for canid herpesvirus- 1 (positive (+)/negative (-)) in $\mathbf{5 7}$ puppies from 37 litter submitted for necropsy.

Additional file 2: Map showing the geographical origin of puppies (litters) submitted for examination for canid herpesvirus-1 in Denmark, September 2012 to April 2013.

Additional file 3: Real-time polymerase chain reaction assay for canid herpesvirus-1. Results of crossing point values (Cp) of undiluted, 1:10 and 1:100 dilutions.

\section{Competing interests}

JSA is editor-in-chief of Acta Veterinaria Scandinavia, but has not in any way been involved in or interacted with the review process or editorial decision making. The authors declare they have no competing interests. HJB is employed by Vet Med Labor GmbH, Division of IDEXX Laboratories, which is offering the applied PCR assay commercially. Merial Norden A/S is the manufacturer of a vaccine against CaHV-1 infection in dogs and has funded parts of the study. Employees from Merial Norden A/S have not participated in analyses or data interpretation or in any way interfered with manuscript preparation.

\section{Authors' contributions}

RWL and JSA conceived the study. RWL performed the necropsies and tissue collection. JSA performed the histopathological examination while MK conducted the ISH examination. HJB performed the PCR analyses. RWL and JSA drafted the manuscript. All authors have read and approved the final manuscript.

\section{Acknowledgments}

The study was financially supported by the Danish Kennel Club and Merial Norden A/S.

\section{Author details}

${ }^{1}$ Section for Veterinary Reproduction and Obstetrics, Department of Large Animal Sciences, Faculty of Health and Medical Sciences, University of Copenhagen, Dyrlægevej 68, Frederiksberg DK-1870, Denmark. ${ }^{2}$ Department of Pathobiology and Diagnostic Investigation, Diagnostic Center for Population and Animal Health Michigan State University, Lansing, MI 48910, USA. ${ }^{3}$ Vet Med Labor GmbH, Division of IDEXX Laboratories, Ludwigsburg D-71636, Germany.

Received: 25 June 2014 Accepted: 19 December 2014

Published online: 08 January 2015

\section{References}

1. Dubovi EJ, Maclachlan NJ. Herpesvirales. In: Dubovi EJ, Maclachlan NJ, editors. Fenner's Veterinary Virology. 4th ed. Oxford, UK: Elsevier Inc, Boston; 2010. p. 179-95.

2. Greene CE. Canine Herpesvirus Infection. In: Greene CE, editor. Infectious Diseases of the Dog and Cat. 4th ed. Philadelphia, PA: Saunders; 2012. p. 48-54.

3. Carmichael LE, Squire RA, Krook L. Clinical and pathologic features of a fatal viral disease of newborn pups. Am J Vet Res. 1965;26:803-14.

4. Hashimoto A, Hirai K, Yamaguchi T, Fujimoto Y. Experimental transplacental infection of pregnant dogs with canine herpesvirus. Am J Vet Res. 1982;43:844-50

5. Hashimoto A, Hirai K, Suzuki Y, Fujimoto Y. Experimental transplacental transmission of canine herpesvirus in pregnant bitches during the second trimester of gestration. Am J Vet Res. 1983;44:610-4.

6. Decaro N, Martella V, Buonavoglia C. Canine adenoviruses and herpesvirus. Vet Clin Small Anim. 2008;38:799-814. 
7. Carmichael LE. Herpesvirus canis: aspects of pathogenesis and immune response. J Am Vet Med Assoc. 1970;156:1714-21.

8. Carmichael LE, Barnes FD, Percy DH. Temperature as a factor of resistance of young puppies to canine herpesvirus. J Infect Dis. 1969;120:669-78.

9. Rootwelt V, Lund A, Krogenæs A. Herpes virus infection in the dog - A review. Norsk Vettidskr. 2009:121:339-47.

10. Indrebø A, Trangerud C, Moe L. Canine neonatal mortality in four large breeds. Acta Vet Scand. 2007:49 Suppl 1:S2.

11. Gill MA: Perinatal and Late Neonatal Mortality in the Dog. PhD thesis. University of Sydney; 2001.

12. Münnich A. The pathological newborn in small animals: the neonate is not a small adult. Vet Res Comm. 2008:32 Suppl 1:S81-5.

13. Love DN, Huxtable CRR. Naturally-occurring neonatal canine herpesvirus infection. Vet Rec. 1976;99:501-3.

14. Rijsewijk FAM, Luiten EJ, Daus FJ, Van der Heijden RW, Van Oirschot JT. Prevalence of antibodies against canine herpesvirus 1 in dogs in The Netherlands in 1997-1998. Vet Microbiol. 1999:65:1-7.

15. Reading MJ, Field HJ. A serological study of canine herpes virus-1 infection in the English dog population. Arch Virol. 1998;143:1477-88.

16. Ronsse V, Vestergen J, Onclin K, Guiot AL, Aeberlé C, Nauwynck HJ, et al. Seroprevalence of canine herpesvirus-1 in the Belgian dog population in 2000. Reprod Dom Anim. 2002;37:299-304.

17. Krogenæes A, Rootwelt V, Larsen S, Sjøberg EK, Akselsen B, Skår TM, et al. A serological study of canine herpes virus-1 infection in the Norwegian adult dog population. Theriogenology. 2012;78:153-8.

18. Krogenaes A, Rootwelt V, Larsen S, Renström L, Farstad W, Lund A. A serological study of canine herpesvirus-1 infection in a population of breeding bitches in Norway. Acta Vet Scand. 2014;56:19.

19. Gadsden BJ, Maes RK, Wise AG, Kiupel M, Langohr IM. Fatal canid herpesvirus 1 infection in an adult dog. J Vet Diagn Invest. 2012;24:604-7.

20. Poulet H, Guigal M, Soulier M, Leroy V, Fayet J, Minke G. Protection of puppies against canine herpesvirus by vaccination of the dams. Vet Rec 2001;148:691-5

21. Goldstein T, Mazet JAK, Lowenstine $\sqcup$, Gulland FMD, Rowles TK, King DP et al. Tissue distribution of phocine herpesvirus-1 (PhHV-1) in infected harbour seals (Phoca vitulina) from the Central Californian Coast and a comparison of diagnostic methods. J Comp Pathol. 2005;133:175-83.

\section{Submit your next manuscript to BioMed Central} and take full advantage of:

- Convenient online submission

- Thorough peer review

- No space constraints or color figure charges

- Immediate publication on acceptance

- Inclusion in PubMed, CAS, Scopus and Google Scholar

- Research which is freely available for redistribution 